JURNAL AL BAYAN: JURNAL JURUSAN PENDIDIKAN BAHASA ARAB

p-ISSN 2086-9282 | e-ISSN 2549-1229

\title{
The Pronunciation of Egyptian Arabic and Its Aspect of Sociolinguistic
}

\author{
Fitra Nanda ${ }^{1}$, Rika Astari*2 ${ }^{2}$, Haji Mohammad bin Seman ${ }^{3}$ \\ ${ }^{1}$ Arabic Language and Literature Study Program Universitas Ahmad Dahlan Yogyakarta, Indonesia \\ ${ }^{2}$ Arabic Language and Literature Study Program Universitas Ahmad Dahlan Yogyakarta, Indonesia \\ ${ }^{3}$ Arabic Language and Middle Eastern Languages Study Program UM, Malaysia
}

Article History:

Received : January 18, 2020

Revised : February 25, 2020

Accepted : March 28, 2020

Published : December 01, 2020

\section{Keywords:}

Characteristic; Morphological;

Phonological; Variations

*Correspondence Address:

rika.astari@bsa.uad.ac.id

\begin{abstract}
The purpose of this research is to provide insight into the characteristics of the Amiyah Egyptian language from a sociolinguistic point of view. This research was conducted by examining a variety of literature relating to the object of study and also the deepening of the material regarding sociolinguistics itself. The research method applies note taking, which takes data from YouTube consisting of 10 video objects whose results are presented in descriptive form. The procedure taken is 1) listening to every phrase spoken by the speaker, 2) recording vocabulary that has phonological differences with Arabic Fusha, 3) classifying data according to sound change prepositions, 4) analyzing data related to phonological and morphological aspects, 5) doing further analysis related to the sociolinguistic point of view, 6) presents the results of the study. The results of this study, Arabic amiyah is not included as a language but a dialect that emerges from a basic language, namely Arabic fusha. Although the amiyah language has different phonological and morphological aspects that have become characteristic of being another language. This was explained by the social conditions of the Egyptian community who held that the language variations formed were higher social classes than the existing basic language namely fusha language.
\end{abstract}

\section{Introduction}

Language is an utterance that is spoken and written ${ }^{1}$. If we notice it, there is a further understanding. Language is a system of sound signs which is used by humans to interact with each other ${ }^{2}$. To interact, someone uses language and lexical choices which have meaning ${ }^{3}$ as a medium used by humans to communicate and produce the meaning ${ }^{4}$.

${ }^{1}$ Meilan Arsanti, "Pemerolehan Bahasa Pada Anak (Kajian Psikolinguistik)," Jurnal PBSI 3, no. 2 (2014): 24-47.

${ }^{2}$ Ahmad Izzan, Metodologi Pembelajaran Bahasa Arab (Bandung: Humaniora, 2015).

${ }^{3}$ Rika Astari and Betty Mauli Rosa Bustam, "A Semantic AnalysisOf Difference Lexical Choices In Quran Translation Of Indonesian And Dutch Versions," Arabiyat: Jurnal Pendidikan Bahasa Arab dan Kebahasaaraban 6, no. 2 (2019): 302-321.

${ }^{4}$ Rika Astari et al., "Padanan Kosakata Arab Dalam Al-Qur'an Terjemah Versi Indonesia Dan Malaysia," Arabi: Journal of Arabic Studies 5, no. 1 (2020): 63-78. 
Arabic is divided into two functions, namely as the language for daily communication ${ }^{5}$ and also the language of art. Arabic is a very complex language from its grammatical structure $^{6}$. Classical Arabic is part of fusha Arabic (formal), as well as Modern Standard Arabic ${ }^{7}$.

The difference between classical Arabic and Modern Standard Arabic is on the type of time in the language. If classical Arabic is the language used by Quraish in the era of Prophet Muhammad, Modern Standard Arabic ${ }^{8}$ is the language which is used commonly nowadays by borrowing some foreign vocabulary, it is in contrast to classical Arabic which is still pure. Amiyah language is a non-formal language or what is also called as market Arabic ${ }^{9}$ or local Arabic. ${ }^{10}$ According to Emil Badi 'Ya'qub in his writings on Perbedaan Bahasa Arab Ragam Fusha dan Amiyah ${ }^{11}$ (Differences of Arabic Language Variety of Fusha and Amiyah) states that this Amiyah language is nothing but used as a social language by the Arab community. This language has a different forum from the Fusha language, even so, for example, the Amiyah Egyptian language itself can be understood by Arabs from other territories such as Saudi Arabia and Morocco.

Egypt is a country that is one of the oldest countries in the world ${ }^{12}$ consisting of various ethnicities $^{13}$ and as explained above, Arabic entered Egypt at the same time that Islamic teachings ${ }^{14}$ were brought there along with the wider expansion during the

\footnotetext{
${ }^{5}$ Naeila Rifatil Muna, "Psikologi Pembelajaran Bahasa Arab," El-Ibtikar: Jurnal Pendidikan Bahasa Arab 1, no. 1 (2016): 102-126.

${ }^{6}$ Peter Petré and Van de Velde Freek, "The Real-Time Dynamics of the Individual and the Community in Grammaticalization," Linguistic Society of America Language 94, no. 4 (2018): 867-901.

${ }^{7}$ Dedi Supriyanto, "Perbedaan Bahasa Arab Mesir Ragam Fusha Dan Amiyah," July 10, 2019, accessed January 6, 2020, https://p4tkbahasa.kemdikbud.go.id/2019/07/10/perbedaan-bahasa-arab-mesirragam-fusha-dan-amiyah/.

${ }^{8}$ Abd Aziz, "Landasan Pikir Perdebatan Eksistensi Bahasa Arab Fusha Dan 'Ammiyah," Al Amin: Jurnal Kajian Ilmu dan Budaya Islam 2, no. 2 (2019): 117-129.

${ }^{9}$ Misran, "Dialek 'Ammiyyah Dalam Pengajaran Bahasa Arab Untuk Pariwisata Di Indonesia," Adabiyyāt: Jurnal Bahasa dan Sastra 12, no. 2 (2013): 398-423.

${ }^{10}$ Muhammad Noupal, "Bahasa Arab 'Amiyah Dan Fushah Suatu Narasi Deskriptif," Jurnal AlBayan 1, no. 2 (2010): 1-11.

${ }^{11}$ Supriyanto, "Perbedaan Bahasa Arab Mesir Ragam Fusha Dan Amiyah."

${ }^{12}$ Central Intelligence Agency, "The World Factbook," December 2019, accessed January 10, 2020, https://www.cia.gov/library/publications/the-world-factbook/geos/eg.html.

${ }^{13}$ Derek Hopwood et al., "Arab Republic of Egypt, Arab Socialist Republic, Jumhūrīyat Miṣr al'Arabīyah, Mișr.," Encyclopedia Britannica, October 2019, accessed January 10, 2020, https://www.britannica.com/place/Egypt.

${ }^{14}$ Muhammah Dzulfikriddin, Sejarah Politik Indonesia: Peran Dan Jasa Mohammad Natsir Dalam Dua Orde Indonesia (Bandung: Mizan Pustaka, 2010).
} 
Umayyad dynasty $^{15}$. Furthermore, Egyptian society used Arabic in two conditions ${ }^{16}$, namely formal and informal ${ }^{17}$. The Arabic language differs both phonologically and morphologically, in brief, it makes Egyptian society a general practitioner of diglossia. Diglossia meaning is taken from the French term diglossie, which is used to express a situation where there are two variations of one language that coexist and each has a specific role ${ }^{18}$. Ferguson states that diglossia has an assumption foundation in which the speaking community considers a language and another language has two levels called high language and low language, in symbolism it is denoted by $\mathrm{T}$ for high variety and $\mathrm{R}$ for low variety ${ }^{19}$. Fusha Arabic is included in the high variety and Amiyah Arabic is included in the low variety.

In modern times, diglossia is something that is acceptable in society. In Egyptian society, this significant difference actually creates a problem because Amiyah is a language that is easier, more flexible, and actual than Fusha. Amiyah language itself is a dialect that occurs in Arabic, Ahmad Haryono ${ }^{20}$ argues that dialect occurs from the process of moving a language speaker to another speaker environment, resulting in a new dialect, creating new vocabulary, even changing the syntactic ${ }^{21}$. It also changes the grammatical structure ${ }^{22}$ that maintains grammatical compatibility. Thus, the differences that have been described previously cause the problem like the persuasion to not use the Amiyah language, but this has received criticism from other parties who have the view that Fusha is a language that needs to be preserved ${ }^{23}$ because it is the language of unity

\footnotetext{
${ }^{15} \mathrm{C}$. Ceyhun Arslan, "Entanglements between the Tanzimat and Al-Nahḍah: Jurjī Zaydān between Tārīkh Ādāb al-Lughah al-Turkiyyah and Tārīkh Ādāb al-Lughah al-'arabiyyah," Journal of Arabic Literature 50, no. 3-4 (2019): 298-324.

${ }^{16}$ Mariam Aboelezz, "The Politics of Pro-āmmiyya Language Ideology in Egypt" (Leiden, The Netherlands: Brill, 2017), 212-238, https://brill.com/view/book/edcoll/9789004346178/B9789004346178s011.xml.

${ }^{17}$ Mufrodi, "Fonologi Dan Morfologi Bahasa Arab Amiyah Mesir," Arabiyat: Jurnal pendidikan Bahasa Arab dan Kebahasaaraban 2, no. 2 (December 2015): 192-215.

${ }^{18}$ Achmad Tohe, "Bahasa Arab Fusha Dan Amiyah Serta Problematikanya," Jurnal Bahasa dan Seni 33 (2005): 202.

${ }^{19}$ Widi Astuti, "Diglossia Pada Penggunaan Bahasa Arab (Kajian Kebahasaan Terhadap Bahasa Fusha Dan Bahasa Amiyah Dilihat Dari Prespektif Sosiolinguistik" 6, Jurnal Komunikasi dan Pendidikan Islam (Desember 2017): 147.

${ }^{20}$ Haryono Akhmad, "Perubahan Dan Perkembangan Bahasa: Tinjauan Historis Dan Sosiolinguistik" (Doctoral Dissertation, Udayana University, 2012).

${ }^{21}$ S. Poedjosoedarmo, "Perubahan Bahasa," in Ceramah Ilmiah Linguistik Pada Pusat Kajian Melayu-Jawa (Fakultas Sastra Universitas Sebelas Maret Surakarta, 2008).

${ }^{22}$ David Deterding, "Mellisa A. Redford (Ed.), The Handbook of Speech Production. Malden, MA: Wiley-Blackwell, 2015. Pp. Xii 601. ISBN: 978-0-470-65993-9 (Hbk)," Journal of the International Phonetic Association 48, no. 2 (2018): 253-286.

${ }^{23}$ Sofía Torallas Tovar, 'Linguistic Identity in Graeco-Roman Egypt.' The Multilingual Experience in Egypt, from the Ptolemies to the Abbasids," Routledge (2016): 27-56.
} 
in Arab community ${ }^{24}$. Even though, in the context of the Amiyah Egyptian language itself still has different grammatical references from Fusha Arabic ${ }^{25}$.

Based on the study above, this article aims to examine how to pronounce Egyptian Arabic and the relationship between the language and speakers of the dialect ${ }^{26}$. In connection with the discussion regarding the study of Arabic pronunciation, in 2015 Ibrahim Eltouhamy conducted a study on the effect of the use of the Amiyah Egyptian dialect on the attitudes of language users, dialects commonly used in Egypt are FallaHi and Saiidi ${ }^{27}$. The research was conducted for speakers of each language by distinguishing the gender between men and women ${ }^{28}$. Some differences in the aspects of intelligence, decision-making skills, leadership, but it does not show a significant number. Then, the writer found various writings that researched about the pronunciation in Arabic which is found in Al-Qur'an. One of them can be found in the writings of Muhammad Afif Amrulloh entitled Kesamaan Bunyi pada Sajak (Kajian Fonologi al-Qur'an dalam Surat al 'Asar) (Similarities to the Sounds of the Verses (Study of the Phonology of al-Qur'an in Surah al 'Asar)) which provides an explanation of the similarities in Arabic pronunciation patterns contained in Surah al' Asar $^{29}$.

Furthermore, sociolinguistics is a branch of linguistics, which focuses on the study of things that are emphasized outside the scope of language ${ }^{30}$, and even in its own sociolinguistic view, a language is not considered a language but a means between individuals to understand each other. In this term, sociolinguistics is the study of the character of language and the user in their daily interactions, sociolinguistics is a branch of linguistics that studies all aspects of the relationship between language and society ${ }^{31}$. A further study of the factors that caused Amiyah language to occupy an important

\footnotetext{
${ }^{24}$ Astuti, "Diglossia Pada Penggunaan Bahasa Arab (Kajian Kebahasaan Terhadap Bahasa Fusha Dan Bahasa Amiyah Dilihat Dari Prespektif Sosiolinguistik."

${ }^{25}$ Afridesy Puji Pancarani, Zaqiatul Mardiah, and Miranda Ariadna Ayu, "Bahasa Amiyah Mesir (sejarah, Kaidah, dan Perbedaannya dengan Bahasa Arab Klasik" 3, jurnal Al Azhar Indonesia Seri Humaniora (March 2016): 205.

${ }^{26}$ Hoda El Shakry, "In the Shadow of World Literature: Sites of Reading in Colonial Egypt , Written by Michael Allan," Journal of Arabic Literature 48, no. 3 (2017): 345-349.

${ }^{27}$ Ibrahim Eltouhamy, "Language Attitudes towards Dialects of Arabic in Egypt" (Thesis, the American University in Cairo, 2015).

${ }^{28}$ Özlem Göner and Maria Six-Hohenbalken, "Gender and Memory in the Middle East: On Transgenerational Transmission and Agency," Dialectical Anthropology 43, no. 2 (June 1, 2019): 157-159.

${ }^{29}$ Muhammad Afif Amrulloh, "Kesamaan Bunyi Pada Sajak (Kajian Fonologi al-Qur'an Dalam Surat al 'Asar)," Jurnal Al Bayan: Jurnal Jurusan Pendidikan Bahasa Arab 9, no. 1 (2017): 99-109.

${ }^{30}$ Wahyudi and Muhammad Ridha, "Urgensi Mempelajari Psikolinguistik Terhadap Pembelajaran Bahasa," Jurnal Islamika 17, no. 1 (2017): 113-140.

${ }^{31}$ Yendra, Mengenal Ilmu Bahasa (Linguistik), 1st ed. (Yogyakarta: Deepublish, 2018).
} 
position for the Egyptian population. This seems to show that Amiyah is a language of pride for the Egyptian people, this was also conveyed by Reem Bassiouney in his journal Language and Identity in Modern Egypt which was reviewed by Willam Cotter $^{32}$ who said that pride in identity was increasing every time, then had a drastic increase when the Arab Spring ${ }^{33}$ revulsion movement emerged.

In a sociolinguistic perspective, there are many factors that influence so that something like this can happen. In this case, Egyptian society is called as a diglossian society which uses two different dialects in one language ${ }^{34}$. Taken from other journals, the case of Egyptian society Arabic in showing their social identity in Amiyah cannot be separated from the strong influence of the inheritance of the community ${ }^{35}$.

\section{Method}

Qualitative descriptive method ${ }^{36}$ is used which interprets a phenomenon by describing the interpretation in words ${ }^{37}$. Note-taking method of the language speaker's pronunciation is used as data retrieval which the author summarizes through an online platform, Youtube ${ }^{38}$, the results of the recording are classified based on the difference in sound changes of each vocabulary. Thus, an analysis of the main study is done based on the data that has been obtained.

\section{Result and Discussion}

Concerning to disciplinary studies that include dimensions of age, gender, social class, level of education, subject matter, regional origins ${ }^{39}$ in Egyptian Arabic objects, it does not seem as complex as in Fusha Arabic, as mentioned earlier that the Amiyah

\footnotetext{
${ }^{32}$ Reem Bassiouney, "Language and Identity in Modern Egypt," Al- Arabiyya: Journal of the American Association of Teachers of Arabic, no. 49 (2016): 163-166.

${ }^{33}$ Levi Thompson, "Modern Arabic Poetry: Revolution and Conflict, Written by Waed Athamneh," Journal of Arabic Literature 48, no. 3 (2017): 340-344.

${ }^{34}$ James E. Montgomery, "Al-Jāḥiz on Misarticulation: Bayān 1.34.4-74.8," Journal of Arabic Literature 49, no. 1-2 (May 2018): 1-22.

${ }^{35}$ Enam Al-Wer and Uri Horesh, The Routledge Handbook of Arabic Sociolinguistics (New York: Routledge, 2019).

${ }^{36}$ Albi Anggito and Johan Setiawan, Metodologi Penelitian Kualitatif (Sukabumi: CV Jejak, 2018).

${ }^{37}$ Mohammad Siddik, Pengembangan Model Pembelajaran Menulis Deskripsi (Malang: Tunggal Mandiri Publishing, 2018).

${ }^{38}$ David Eribka Ruthellia, Mariam Sondakh, and Stefi Harilama, "Pengaruh Konten Vlog Dalam Youtube Terhadap Pembentukan Sikap Mahasiswa Ilmu Komunikasi Fakultas Ilmu Sosial Dan Politik Universitas Sam Ratulangi," Acta Diurna Komunikasi 6, no. 1 (2017): 1-18.

${ }^{39}$ Michael H Long, Gisela Granena, and Yucel Yilmaz, "Major Research Issues in Sla," Brill Research Perspectives in Multilingualism and Second Language Acquisition 1, no. 1 (2016): 1-86.
} 
Egyptian language puts forward the concept of simplicity, hence the difference in the dimensions is simplified. However, the scope of the use of Fusha language by the Egyptian community is indeed found in the scope of the educated community in the education area as well if it is seen at the social class of the use of the Fusha language in that community, while Amiyah language is very common and naturally spoken there, it might even sound strange if someone speaks Fusha among the Egyptian in general.

Based on the study of the social aspects of language presented by Suhardi and Sembiring, language has variations which show that language cannot be separated from the influence of non-language aspects ${ }^{40}$. In other words, language is supposed to have a variety, even the concept of language diversity appears when researchers link the language process with the speaking community of a language.

A further discussion regarding this diversity is communication events include three things, namely Field, Tenor, and Mode. Field is a term that refers to topics that discuss what language is used. Field is a subject or topic of discussion in the text, so when the vocabulary is about ذ قعد (shop), محز (favorite), مح تاج ين (need), and ق قهو ه (coffee), a sphere that will appear is discussion about the situation a place to drink as its field. Tenor is the relationship between the role of the speech participants or the conversation, which is the social relationship between the speaker and the interlocutor. Tenor emphasizes the choice of language which is influenced by social relations. In the object of this study, it can be seen that tenor occurs when Egyptian speak Amiyah in general while Fusha language is used in the formal condition. The way of referring to the role of that language which plays in communication includes the roles related to the way how it is used in communication. The way here means get through what a message is conveyed, it can be oral, written, written to be spoken, and verbally to be written. The mode here can include language namely persuasive, expository, or narrative. The following is a description of the data from the object of study:

\footnotetext{
${ }^{40}$ Kushartati, Untung Yuwono, and Multamia RMT Lauder, eds., Pesona Bahasa: Langkah Awal Memahami Linguistik (Jakarta: PT Gramedia Pustaka Utama, 2005).
} 


\section{Egyptian Arabic Pronunciation}

Table 1. The Classification of Sound Change

\begin{tabular}{|c|c|c|c|c|c|c|}
\hline No. & Distribution & Word & $\begin{array}{l}\text { Phonetic } \\
\text { Transcription }\end{array}$ & Pronounced & $\begin{array}{l}\text { Phonetic } \\
\text { Transcription }\end{array}$ & Sound Change \\
\hline 1. & & قهوه & [qahwah] & عهوه & [?ahwa] & $\begin{array}{l}\text { [q] to be } \\
\text { [?] }\end{array}$ \\
\hline 2. & & انت & [Panta] & إنت & [?inta] & $\begin{array}{l}\text { [Pa] to be } \\
\text { [?i] }\end{array}$ \\
\hline 3. & & جذيلا & [dzaði:lan] & جذيلا & [ğaði:lan] & $\begin{array}{l}\text { [dza] to be } \\
\text { [ğa] }\end{array}$ \\
\hline 4. & Front & جدا & [dziddan] & جدا & [ǧiddan] & $\begin{array}{l}\text { [dzi] to be } \\
\text { [ği] }\end{array}$ \\
\hline 5. & & مالجديد & [ma:ldzadi:d] & إالجديد & [inǧi:d] & $\begin{array}{l}\text { [ma:ldzad] to be } \\
\text { [inğ] }\end{array}$ \\
\hline 6. & & 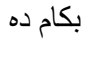 & [bika:m dah] & بكام ده & [beka:m dah] & $\begin{array}{l}{[\mathrm{bi}] \text { to be }} \\
\text { [be] }\end{array}$ \\
\hline 7. & Middle & ممكن & [mumkin] & منكن & [muykin] & $\begin{array}{l}{[\mathrm{m}] \text { to be }} \\
{[\mathrm{y}]}\end{array}$ \\
\hline 8. & & اثنان & [ïna:n] & اتنان & [itna:n] & $\begin{array}{l}{[\theta] \text { to be }} \\
{[\mathrm{t}]}\end{array}$ \\
\hline 9. & & مترجم & [mutardsim] & مترجم & [motarğem] & $\begin{array}{l}\text { [dsi] to be } \\
\text { [ğe] }\end{array}$ \\
\hline 10 & & اعمال & [radzul PaSmla:1] & رجل اعمال & $\begin{array}{l}\text { [roğul } \\
\text { PaSma:1] }\end{array}$ & $\begin{array}{l}{[\mathrm{d}] \text { to be }} \\
{[\mathrm{g}]}\end{array}$ \\
\hline 11 & & هجبلك & [hadzabaluka] & هجبلك & [haǧeblak] & $\begin{array}{l}\text { [dza] to be } \\
\text { [ğe] }\end{array}$ \\
\hline & Back & مزاج & [miza:dz] & مزاج & [mazaǧ] & $\begin{array}{l}{[\mathrm{d}] \text { to be }} \\
{[\mathrm{g}]}\end{array}$ \\
\hline 13 & & محتاجه & [muhta: dzah] & محتاج & [maћta: ğ] & $\begin{array}{l}{[\mathrm{d}] \text { to be }} \\
{[\text { ğ] }}\end{array}$ \\
\hline
\end{tabular}

Furthermore, the author will classify the changes based on the letters that affect them.

Table 2. Sound Change from a to be $\&$

\begin{tabular}{|c|c|c|c|c|c|}
\hline No. & Distribution & $\begin{array}{l}\text { Fusha Arabic } \\
\text { Language }\end{array}$ & $\begin{array}{l}\text { Phonetic } \\
\text { Transcription }\end{array}$ & $\begin{array}{l}\text { Amiyah Egyptian } \\
\text { language }\end{array}$ & $\begin{array}{l}\text { Phonetic } \\
\text { Transcription }\end{array}$ \\
\hline 1. & Front & قهوه & [qahwah] & ك ه هوه & [?ahwa] \\
\hline 2. & Front & قمر & [qamar] & أمر & [a?mar] \\
\hline 3. & Front & قميص & [qomi: $\mathrm{s}^{\mathrm{Q}}$ ] & أميص & [Pame:s $\left.{ }^{\complement}\right]$ \\
\hline 4. & Middle & عقبالك & [Saqba:luka] & عئبالك & [oSbalak] \\
\hline 5. & Middle & نقعد & [nuqSud] & نئعد & [nuSud] \\
\hline 6. & Middle & سبقني & [sabaqoni:] & سبئني & [saba?ani:] \\
\hline 7. & Middle & سرقة & [sariqatu] & سر ائة & [sera?a] \\
\hline
\end{tabular}

This table shows that change of sound ق to is very common in Amiyah Egyptian. Based on the distribution of changes, it often occurs in front and center. The possibility of this change is due to the sound difference between the two consonants if the way to pronounce the letter $\mathrm{G}$ is not plosive in the uvular part. 
Table 3. Sound Change from $ث$ to be $ث$

\begin{tabular}{|c|c|c|c|c|c|}
\hline No. & Distribution & $\begin{array}{l}\text { Fusha Arabic } \\
\text { Language }\end{array}$ & $\begin{array}{l}\text { Phonetic } \\
\text { Transcription }\end{array}$ & $\begin{array}{l}\text { Amiyah Egyptian } \\
\text { Language }\end{array}$ & $\begin{array}{l}\text { Phonetic } \\
\text { Transcription }\end{array}$ \\
\hline 1. & Front & مثلاثة & 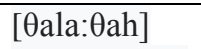 & تلاتة & [tala:tah] \\
\hline 2. & Front & ثمانين & [Өama:nijah] & تمانين & [tama:nija] \\
\hline 3. & Front & ت تثلاثين & [Oala: $\theta \mathrm{i}: \mathrm{n}]$ & ت تلاتين & [tala: ti:n] \\
\hline 4. & Middle & اثنان & [ïna:n] & اتنان & [itna:n] \\
\hline
\end{tabular}

In this table, the change in the pronunciation of consonant sound is also found in the $ت$ consonant which has ' $t s a$ ' orthography in Fusha Arabic, while in Amiyah Egyptian Arabic, it has ' $t a$ ' orthography. It can be found that in the Egyptian language, there is a simplification of the pronunciation which eliminates the fricative $s$ in the pronunciation of the consonants.

Table 4. Sound Change from $ج$ to be

\begin{tabular}{|c|c|c|c|c|c|}
\hline No. & Distribution & $\begin{array}{l}\text { Fusha Arabic } \\
\text { Language }\end{array}$ & $\begin{array}{l}\text { Phonetic } \\
\text { Transcription }\end{array}$ & $\begin{array}{l}\text { Amiyah Egyptian } \\
\text { Language }\end{array}$ & $\begin{array}{l}\text { Phonetic } \\
\text { Transcription }\end{array}$ \\
\hline 1. & Front & جذيلا & [dzaði:lan] & جذيلا & [ğaði:lan] \\
\hline 2. & Front & جدا & [dziddan] & جدا & [ğiddan] \\
\hline 3. & Front & جميل & [dzami:1] & جميل & [ğami:1] \\
\hline 4. & Front & جعان & [dzuYa:n] & جعان & [ğaSa:n] \\
\hline 5. & Front & جبت & [dgabat] & جبت & [ǧebt] \\
\hline 6. & Middle & ما مالجديد & [ma:Idzadi:d] & إلجديد & [inği:d] \\
\hline 7. & Middle & هجر & [ћadzar] & هجر & [hağar] \\
\hline 8. & Middle & محتاجين & [maћta:dzi:n] & محتاجين & [mahtaği:n] \\
\hline 9. & Middle & مترجم & [mutardgim] & مترجم & [motarǧem] \\
\hline 10. & Middle & رجل اعمال & $\begin{array}{l}\text { [radzul } \\
\text { Pa\&ma:1] }\end{array}$ & رجل اعمال & [roǧul Pa@ma:1] \\
\hline 11. & Back & مزاج & [miza:d3] & مزاج & [mazaǧ] \\
\hline 12. & Back & محتاجه & [muћta: dzah] & محتاجه & [maћta: ğ] \\
\hline
\end{tabular}

The sound change in the $\mathrm{c}$ consonant is dominant in the data. The consonant $\mathrm{e}$, which in Arabic fusha has $J a$ orthographic, changes in Amiyah Egyptian to $G a$. This is a change that is very often found there, even though it includes distributions in front, middle, and back.

Table 5. Sound Change from L to be إl

\begin{tabular}{clllll}
\hline No. & Distribution & $\begin{array}{l}\text { Fusha Arabic } \\
\text { Language }\end{array}$ & $\begin{array}{l}\text { Phonetic } \\
\text { transcription }\end{array}$ & $\begin{array}{l}\text { Amiyah Egyptian } \\
\text { language }\end{array}$ & $\begin{array}{l}\text { Phonetic } \\
\text { transcription }\end{array}$ \\
\hline 1. & Front & مالجديد & [?anta] & & [inği:d] \\
\hline
\end{tabular}

Tabel 6. Sound Change from ب[bi] to be ب [be]

\begin{tabular}{llllll}
\hline & Distribution & $\begin{array}{l}\text { Fusha Arabic } \\
\text { Language }\end{array}$ & $\begin{array}{l}\text { Phonetic } \\
\text { transcription }\end{array}$ & $\begin{array}{l}\text { Amiyah Egyptian } \\
\text { language }\end{array}$ & $\begin{array}{l}\text { Phonetic } \\
\text { transcription }\end{array}$ \\
\hline 1. & Front & بكام ده & [bika:m dah] & & [beka:m dah]
\end{tabular}


Table 7. Sound Change from ![?i:] to be ! [?e:]

\begin{tabular}{|c|c|c|c|c|c|}
\hline No. & Distribution & $\begin{array}{l}\text { Fusha Arabic } \\
\text { Language }\end{array}$ & $\begin{array}{l}\text { Phonetic } \\
\text { transcription }\end{array}$ & $\begin{array}{l}\text { Amiyah Egyptian } \\
\text { language }\end{array}$ & $\begin{array}{l}\text { Phonetic } \\
\text { transcription }\end{array}$ \\
\hline 1. & Front & إيه & [Pi:h] & إيه & [Pe:h] \\
\hline 2. & Front & انت منين & $\begin{array}{l}\text { [?anta } \\
\text { minajna] }\end{array}$ & انت منين & [?enta mnijn] \\
\hline 3. & Front & إزيك & [Pizi:k] & إزيك & [?eza:jak] \\
\hline
\end{tabular}

Table 8. Sound Change from $\bullet$ [hu] to be $\bullet[$ ho]

\begin{tabular}{|c|c|c|c|c|c|}
\hline No. & Distribution & $\begin{array}{l}\text { Fusha Arabic } \\
\text { Language }\end{array}$ & $\begin{array}{l}\text { Phonetic } \\
\text { transcription }\end{array}$ & $\begin{array}{l}\text { Amiyah Egyptian } \\
\text { language }\end{array}$ & $\begin{array}{l}\text { Phonetic } \\
\text { transcription }\end{array}$ \\
\hline 1 & Front & هو & [huwa] & هو & [howa] \\
\hline
\end{tabular}

Table 9. Sound Change from $د[$ di:] to bes[de:

\begin{tabular}{llllll}
\hline No. & Distribution & $\begin{array}{l}\text { Fusha Arabic } \\
\text { Language }\end{array}$ & $\begin{array}{l}\text { Phonetic } \\
\text { transcription }\end{array}$ & $\begin{array}{l}\text { Amiyah Egyptian } \\
\text { language }\end{array}$ & $\begin{array}{l}\text { Phonetic } \\
\text { transcription }\end{array}$ \\
\hline 1. & Front & & دي & [di:] & [de: $]$ \\
\hline
\end{tabular}

Table 10. Sound Change from $i$ to be !

\begin{tabular}{|c|c|c|c|c|c|}
\hline No. & Distribution & $\begin{array}{l}\text { Fusha Arabic } \\
\text { Language }\end{array}$ & $\begin{array}{l}\text { Phonetic } \\
\text { transcription }\end{array}$ & $\begin{array}{l}\text { Amiyah Egyptian } \\
\text { language }\end{array}$ & $\begin{array}{l}\text { Phonetic } \\
\text { transcription }\end{array}$ \\
\hline 1. & Front & انت & [?anta] & إنتت & [?inta] \\
\hline 2. & Front & انت منين & $\begin{array}{l}\text { [Panta } \\
\text { minajna] }\end{array}$ & انت منين & [?enta mnijn] \\
\hline
\end{tabular}

Table 11. Sound Change from ب[bi] to beب [ba]

\begin{tabular}{llllll}
\hline No. & Distribution & $\begin{array}{l}\text { Fusha Arabic } \\
\text { Language }\end{array}$ & $\begin{array}{l}\text { Phonetic } \\
\text { transcription }\end{array}$ & $\begin{array}{l}\text { Amiyah Egyptian } \\
\text { language }\end{array}$ & $\begin{array}{l}\text { Phonetic } \\
\text { transcription }\end{array}$ \\
\hline 1. & Front & & بbihub] & & بbihub]
\end{tabular}

Table12. Sound Change from $\varepsilon[$ [i] to be $\varepsilon[$ [ a ]

\begin{tabular}{llllll}
\hline No. & Distribution & $\begin{array}{l}\text { Fusha Arabic } \\
\text { Language }\end{array}$ & $\begin{array}{l}\text { Phonetic } \\
\text { transcription }\end{array}$ & $\begin{array}{l}\text { Amiyah Egyptian } \\
\text { language }\end{array}$ & $\begin{array}{l}\text { Phonetic } \\
\text { transcription }\end{array}$ \\
\hline 1. & Front & & [Sindi:] & & [Sandi:]
\end{tabular}

Table 13. Sound Change from $\varepsilon[$ [ a]to be $\varepsilon[$ [o]

\begin{tabular}{rrrrrrr}
\hline No. & Distribution & $\begin{array}{l}\text { Fusha Arabic } \\
\text { Language }\end{array}$ & $\begin{array}{l}\text { Phonetic } \\
\text { transcription }\end{array}$ & $\begin{array}{l}\text { Amiyah Egyptian } \\
\text { language }\end{array}$ & $\begin{array}{l}\text { Phonetic } \\
\text { transcription }\end{array}$ \\
\hline 1. & Front & [Sagba:luka] & & [o?balak]
\end{tabular}

\begin{tabular}{|c|c|c|c|c|}
\hline \multicolumn{5}{|c|}{ Table14.Sound Change from $i$ to be $i$} \\
\hline No. & Distribution & $\begin{array}{ll}\text { Fusha Arabic } & \text { Phonetic } \\
\text { Language } & \text { transcription }\end{array}$ & $\begin{array}{l}\text { Amiyah Egyptian } \\
\text { language }\end{array}$ & $\begin{array}{l}\text { Phonetic } \\
\text { transcription }\end{array}$ \\
\hline 1. & Front & [uktub] & تبب & [iktib] \\
\hline
\end{tabular}


Table15. Sound Change from $\boldsymbol{\omega}\left[\mathrm{s}^{\mathrm{S}} \mathrm{a}\right]$ to be $\boldsymbol{\omega}\left[\mathrm{s}^{\mathrm{S}} \mathrm{O}\right]$

\begin{tabular}{|c|c|c|c|c|c|}
\hline No. & Distribution & $\begin{array}{l}\text { Fusha Arabic } \\
\text { Language }\end{array}$ & $\begin{array}{l}\text { Phonetic } \\
\text { transcription }\end{array}$ & $\begin{array}{l}\text { Amiyah Egyptian } \\
\text { language }\end{array}$ & $\begin{array}{l}\text { Phonetic } \\
\text { transcription }\end{array}$ \\
\hline 1. & Front & صغير & [s'ayi:r] & صغير & [s'oya:jr] \\
\hline \multicolumn{6}{|c|}{ Table 16. Sound Change from } \\
\hline No. & Distribution & $\begin{array}{l}\text { Fusha Arabic } \\
\text { Language }\end{array}$ & $\begin{array}{l}\text { Phonetic } \\
\text { transcription }\end{array}$ & $\begin{array}{l}\text { Amiyah Egyptian } \\
\text { language }\end{array}$ & $\begin{array}{l}\text { Phonetic } \\
\text { transcription }\end{array}$ \\
\hline 1. & Front & كبير & [kabi:r] & كبير & [kebi:r] \\
\hline
\end{tabular}

Table17. Sound Change from ش[كu:] to be ش[كo:]

\begin{tabular}{llllll}
\hline No. & Distribution & $\begin{array}{l}\text { Fusha Arabic } \\
\text { Language }\end{array}$ & $\begin{array}{l}\text { Phonetic } \\
\text { transcription }\end{array}$ & $\begin{array}{l}\text { Amiyah Egyptian } \\
\text { language }\end{array}$ & $\begin{array}{l}\text { Phonetic } \\
\text { transcription }\end{array}$ \\
\hline 1. & Front & & [Su:rt] & & [Sort] \\
\hline
\end{tabular}

Table18. Sound Change from Iال [a] to be Jlel]

\begin{tabular}{|c|c|c|c|c|c|}
\hline No. & Distribution & $\begin{array}{l}\text { Fusha Arabic } \\
\text { Language }\end{array}$ & $\begin{array}{l}\text { Phonetic } \\
\text { transcription }\end{array}$ & $\begin{array}{l}\text { Amiyah Egyptian } \\
\text { language }\end{array}$ & $\begin{array}{l}\text { Phonetic } \\
\text { transcription }\end{array}$ \\
\hline 1. & Front & الدنيا & [addun ja:] & الدنيا & [eldon ja] \\
\hline 2. & Front & السفارة & [assifa:rotu] & السفارة & [el sefa:ra] \\
\hline 3. & Front & التذاكر & [at taða:kuru] & التذاكر & [el taða:ker] \\
\hline 4. & Front & الخطوبة & [al $\left.\chi u t^{\varsigma} u: b a t u\right]$ & الخطوبة & [el $\chi$ ot $\left.^{\complement} \mathrm{oba}\right]$ \\
\hline 5. & Middle & مساءلخير & 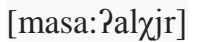 & مساءلخير & [masa:Pel $\chi j \mathrm{r}]$ \\
\hline
\end{tabular}

Table 19. Sound change from Jlal] to be Jlil]

\begin{tabular}{|c|c|c|c|c|c|}
\hline No. & Distribution & $\begin{array}{l}\text { Fusha Arabic } \\
\text { Language }\end{array}$ & $\begin{array}{l}\text { Phonetic } \\
\text { transcription }\end{array}$ & $\begin{array}{l}\text { Amiyah Egyptian } \\
\text { language }\end{array}$ & $\begin{array}{l}\text { Phonetic } \\
\text { transcription }\end{array}$ \\
\hline 1. & Front & اليوم & [aljauma] & اليوم & [il jaum] \\
\hline 2 . & Front & الطرقة & [al t'ari:qah] & الطرقة & [il t t $^{\circ}$ :Pah] \\
\hline
\end{tabular}

In Table 5 to Table 19, there is a change in the sound of the vowel, which changes the pronunciation of the vowels commonly found in Fusha Arabic such as vowel $e$, the vowel $o$, there is even a vowel change from $u$ to $i$ and even $a$ to $i$.

Table 20. Sound Change from باي

\begin{tabular}{|c|c|c|c|c|c|}
\hline No. & Distribution & $\begin{array}{l}\text { Fusha Arabic } \\
\text { Language }\end{array}$ & $\begin{array}{l}\text { Phonetic } \\
\text { transcription }\end{array}$ & $\begin{array}{l}\text { Amiyah Egyptian } \\
\text { language }\end{array}$ & $\begin{array}{l}\text { Phonetic } \\
\text { transcription }\end{array}$ \\
\hline 1. & Front & باشـا & [ba:sa: ] & بايثى & [bajsi] \\
\hline
\end{tabular}

Table21. Sound Change from $\varepsilon$ to be عي

\begin{tabular}{clllll}
\hline No. & Distribution & $\begin{array}{l}\text { Fusha Arabic } \\
\text { Language }\end{array}$ & $\begin{array}{l}\text { Phonetic } \\
\text { transcription }\end{array}$ & $\begin{array}{l}\text { Amiyah Egyptian } \\
\text { language }\end{array}$ & $\begin{array}{l}\text { Phonetic } \\
\text { transcription }\end{array}$ \\
\hline 1. & Middle & & [taSli:] & & [taSajli:] \\
\hline
\end{tabular}

In table 20 and table 21, there is a sound change with the addition of particle The pronunciation of the vowel $[a]$ gets the affix of the particle $[y]$, so it is pronounced as $[a y]$.

Table 32. Sound Change from $\quad \rho[\mathrm{m}]$ to be $\dot{ن}[\mathrm{y}]$ 


\begin{tabular}{ccllll}
\hline No. & Distribution & $\begin{array}{l}\text { Fusha Arabic } \\
\text { Language }\end{array}$ & $\begin{array}{l}\text { Phonetic } \\
\text { transcription }\end{array}$ & $\begin{array}{l}\text { Amiyah Egyptian } \\
\text { language }\end{array}$ & $\begin{array}{l}\text { Phonetic } \\
\text { transcription }\end{array}$ \\
\hline 1. & Middle & مSكن & [mumkin] & & [munkin] \\
\hline
\end{tabular}

In the table above, it can be seen that there is a change from the sound $n$ to the sound $n g$ in the consonant ن. So, it will sound buzzing.

From the explanation that has been described, it can be noted that the difference in language between Amiyah Egyptian and Fusha does not mean that it has a different meaning. This phenomenon seems like the Egyptian people are more inclined to make it easier to pronounce the Fusha Arabic. When compared to Indonesian speech communities, especially Javanese, this phenomenon looks different in Javanese, especially in the Central Java region, which has different social status strata in different dialects ${ }^{41}$.

In addition, Egyptian society seems to have a tendency to speak in a European style which in European languages is rarely pronounced $[j a]$ but $[\mathrm{ga}]$ makes one thing that seems to be characteristic of Egyptian society where the pronunciation of the sound $[\mathrm{Ga}]$ is not found, which is the whole the word that contains the pronunciation changes to the letter $s[\mathrm{~Pa}]$. Of course, over time, the growing demographics and descent of Egyptian Arab society may become Arabic language becoming increasingly faded.

Amiyah language borrows a lot of foreign language vocabulary, especially the language of the colonizers who once occupied Egypt. In fact, almost all Arab countries do not only have one official language, this also shows evidence of the strengthening of the nation that had colonized there in forming a political system, language, and so on. Even though the Egyptians are the perpetrators of diglossia, we do not really know whether they are diglossic or not if you see the tendency of the people to use their own dialect instead of using the pure language of the Fusha.

For example, when the author saw a video of the Egyptian people being interviewed, they still answered in Amiyah, even though the interviewer used Fusha. This phenomenon can make a shift in the position of Arabic itself, especially in this region. Because when they consider the Amiyah language to have a higher position than the Fusha language, it shows a sociolinguistic attitude that began to differ from centuries ago when Fusha Arabic was spoken anywhere, it is still considered a reference to the correct Arabic language which has a higher position. 
Furthermore, in Amiyah Egyptian, the vocabulary which contains the consonants above has a different pronunciation from the Fusha language such as sر ترجم which is pronounced 'mutargim'. The author found the meaning contained in the vocabulary was the same as the meaning if it is pronounced with fusha dialect, namely 'translator'.

Apart from having differences in the pronunciation of consonants, the Amiyah Egyptian language also has difference in the pronunciation of vowels. In Arabic, vowels are divided into 6 types, they are $a, a: i, i:, u, u$ : the letter marked with ' $:$ has an emphasize. In Amiyah Egyptian, the vocals are $a, i, e, o$. It can be seen in the vocabulary $\$$, In Fusha, it is pronounced 'huwa', while in Amiyah Egyptian it is pronounced 'howa', although it has a difference in the pronunciation of both Fusha and Amiyah, it still has the same meaning, namely "He" (refers to a man). However, in some cases, the vowel a can also change to the vowel e, as in the word مـ ساءل خ ير is pronounced 'Masa al khayr' in Fusha Arabic, but in Amiyah Egyptian, it is pronounced 'masa el khayr', there are differences in ' $a l$ ' and ' $e l$ ', namely the change of vowel $a$ to vowel $e$ and although once again there is no difference in meaning there, both Fusha and Amiyah have the same meaning, namely 'good evening'. And also the vowel $u$ can change to $i$ as in the vocabulary in Fusha is pronounced 'uktub' while in Amiyah Egyptian, it is pronounced ' $i k t i b$ ', and has the same meaning, which is 'writing'. Amiyah Arabic shows dialect differences which also have different letters, in Amiyah Egyptian, the letter jim (ج) is written with the addition of three dots.

\section{Sociolinguistic Aspects of Arabic Egyptian Dialect}

In the community there must be various languages. B. Suhardi added that there are various kinds of languages in the community, namely intimate, consultative, casual, formal, and frozen ${ }^{42}$. In the object of the study of the Amiyah Egyptian language, people can find that the Amiyah language is included in the variety of casual language, not included in the official variety. If you look at the consultative variety, the Amiyah Egyptian language can also be categorized into this variety, Based on the function obtained, Amiyah language is a language that gets an image as a language that shows an atmosphere of kinship, brotherhood, and closeness, while Fusha has a scope of functions in the social sphere of the Egyptian-speaking community, which is the language used in special areas such as preaching, prayers, conferences.

\footnotetext{
${ }^{42}$ Ibid.
} 
In code mixing theory, the use of two languages that includes language elements in one language into another consistently ${ }^{43}$. Therefore, what is found in the object of study of Egyptian society is not included in the category of code mixing, because related to how Amiyah language is spoken, it is a dialect of a standard language, namely Fusha. However, in another study, it is stated that the Amiyah Egyptian language is not included in a dialect because it has different phonological and morphological aspects that build $\mathrm{it}^{44}$.

From the statement obtained in the journal by Rika Astari, Arab country has Majma 'al-Lughah which aims to maintain the growth and development of Arabic as the language of science and scientific studies ${ }^{45}$. Hence, this study is more focused on Fusha rather than Amiyah. Due to Amiyah language is a variety that has a lower position than Fusha language, but the tendency of the Egyptian people to use it is still higher.

The social conditions that underlie this for centuries also because Arab nation itself consists of various tribes are the important thing that must be preserved as well as preserved $^{46}$. This social factor has actually been spelled out a lot in various works, meaning that the Amiyah language itself is a form of imagery that shows the existence of an Arab territory itself, coupled with the Arab social situation which is identical to its political system which tends to social upheaval.

\section{Conclusion}

Amiyah Arabic is not a language but a dialect that arises from a basic language, namely Fusha Arabic. Although Amiyah has different phonological and morphological aspects that have characterized other languages, the meaning contained in a word in Amiyah is the same as the meaning in Fusha if it is observed by making an orthography of the language as what can be found in some Arabic consonants which are pronounced with different sounds. The author sees a specific view of that dialect speakers. Amiyah Egyptian language has a special position in the Egyptian region and vice versa, in other Arabic regions which have their own Amiyah language as well. The sound change in Amiyah Egyptian does not affect the change in the basic meaning of the Fusha language.

\footnotetext{
${ }^{43}$ Anis Sholihatin, "Pemilihan Kode Pada Masyarakat Keturunan Arab Di Nyoyontaan, Kota Pekalongan: Kajian Sosiolinguistik" (Universitas Diponegoro Semarang, 2008).

${ }^{44}$ Pancarani, Mardiah, and Ariadna Ayu, "Bahasa Amiyah Mesir (sejarah, Kaidah, dan Perbedaannya dengan Bahasa Arab Klasik."

${ }^{45}$ Rika Astari et al., "Bentuk Ortografi Istilah Serapan Bahasa Inggris Ke Dalam Bahasa Arab," Karwistara 4, no. 3 (2014): 224-330.
} 
Social conditions are the factor in the use of the Amiyah language so that the Amiyah language becomes the social language of the Egyptian people, while Fusha is the language of education which between Amiyah and Fusha languages have different forums of use. In the scope of various fields of linguistics, it can be known that Amiyah language itself has quite clear differences compared to Fusha language, especially in the phonological aspect between the two. However, returning to the original meaning of language, which is a way to convey the meaning or intent of a speaker to the listener, differences in phonological pronunciation will be found and the lexical choice is just another form of conveying the same meaning. Amiyah became popular because the language was impressed it is easier than Fusha. Because of that, even though Amiyah Egyptian is included in the low variety of Arabic, it does not make its speech embarrassing but something to be proud of rather than speaking in Fusha. In terms of the sociolinguistic aspect, this is due to the fact that the frequent interaction of the community is mostly carried out in market and street markets. In showing its existence, there has been a movement from within the region that opposes the use of Fusha, even though the movement has been rejected.

\section{Acknowledgment}

The author would like to thank the Director General of Higher Education Science and Technology Resources Kemenristek Dikti, and Prof. Muhamad Ali, PhD, as Director of the Middle East and Islamic Studies Program, and Academic Supervisor, who always provides renewal insights in Islamic Studies and Arabic Sciences as well as the availability of reference books on Arabic Linguistics.

\section{References}

Aboelezz, Mariam. "The Politics of Pro-āmmiyya Language Ideology in Egypt.” Leiden, The Netherlands: Brill, 2017.

Agency, Central Intelligence. “The World Factbook,” December 2019. Accessed January 10, 2020. https://www.cia.gov/library/publications/the-worldfactbook/geos/eg.html.

Akhmad, Haryono. "Perubahan Dan Perkembangan Bahasa: Tinjauan Historis Dan Sosiolinguistik.” Doctoral Dissertation, Udayana University, 2012.

\footnotetext{
${ }^{46}$ Pancarani, Mardiah, and Ariadna Ayu, "Bahasa Amiyah Mesir (sejarah, Kaidah, dan Perbedaannya dengan Bahasa Arab Klasik."

353 | Jurnal Al Bayan: Jurnal Jurusan Pendidikan Bahasa Arab, 12 (2): 340-356 (2020)
} 
Al-Wer, Enam, and Uri Horesh. The Routledge Handbook of Arabic Sociolinguistics. New York: Routledge, 2019.

Amrulloh, Muhammad Afif. "Kesamaan Bunyi Pada Sajak (Kajian Fonologi al-Qur'an Dalam Surat al 'Asar)." Jurnal Al Bayan: Jurnal Jurusan Pendidikan Bahasa Arab 9, no. 1 (2017): 99-109.

Anggito, Albi, and Johan Setiawan. Metodologi Penelitian Kualitatif. Sukabumi: CV Jejak, 2018.

Arsanti, Meilan. "Pemerolehan Bahasa Pada Anak (Kajian Psikolinguistik)." Jurnal PBSI 3, no. 2 (2014): 24-47.

Arslan, C. Ceyhun. "Entanglements between the Tanzimat and Al-Nahḍa: Jurjī Zaydān between Tārīkh Ādāb al-Lughah al-Turkiyyah and Tārīkh Ādāb al-Lughah al'arabiyyah." Journal of Arabic Literature 50, no. 3-4 (2019): 298-324.

Astari, Rika, and Betty Mauli Rosa Bustam. "A Semantic AnalysisOf Difference Lexical Choices In Quran Translation Of Indonesian And Dutch Versions." Arabiyat: Jurnal Pendidikan Bahasa Arab dan Kebahasaaraban 6, no. 2 (2019): 302-321.

Astari, Rika, Hadi Syamsul, Soepomo Pudjosudarmo, and Suhandano. "Bentuk Ortografi Istilah Serapan Bahasa Inggris Ke Dalam Bahasa Arab." Karwistara 4, no. 3 (2014): 224-330.

Astari, Rika, Yusroh, Abdul Malik, Ahmad Arifin bin Sapar, and Nurina Dyah Putrisari. "Padanan Kosakata Arab Dalam Al-Qur'an Terjemah Versi Indonesia Dan Malaysia." Arabi: Journal of Arabic Studies 5, no. 1 (2020): 63-78.

Astuti, Widi. "Diglossia Pada Penggunaan Bahasa Arab (Kajian Kebahasaan Terhadap Bahasa Fusha Dan Bahasa Amiyah Dilihat Dari Prespektif Sosiolinguistik" 6. Jurnal Komunikasi dan Pendidikan Islam (Desember 2017): 147.

Aziz, Abd. "Landasan Pikir Perdebatan Eksistensi Bahasa Arab Fusha Dan 'Ammiyah." Al Amin: Jurnal Kajian Ilmu dan Budaya Islam 2, no. 2 (2019): 117-129.

Bassiouney, Reem. "Language and Identity in Modern Egypt." Al- 'Arabiyya: Journal of the American Association of Teachers of Arabic, no. 49 (2016): 163-166.

Deterding, David. "Mellisa A. Redford (Ed.), The Handbook of Speech Production. Malden, MA: Wiley-Blackwell, 2015. Pp. Xii 601. ISBN: 978-0-470-65993-9 (Hbk)." Journal of the International Phonetic Association 48, no. 2 (2018): 253286.

Dzulfikriddin, Muhammah. Sejarah Politik Indonesia: Peran Dan Jasa Mohammad Natsir Dalam Dua Orde Indonesia. Bandung: Mizan Pustaka, 2010.

El Shakry, Hoda. "In the Shadow of World Literature: Sites of Reading in Colonial Egypt , Written by Michael Allan." Journal of Arabic Literature 48, no. 3 (2017): 345-349. 
Eltouhamy, Ibrahim. "Language Attitudes towards Dialects of Arabic in Egypt." Thesis, the American University in Cairo, 2015.

Eribka Ruthellia, David, Mariam Sondakh, and Stefi Harilama. "Pengaruh Konten Vlog Dalam Youtube Terhadap Pembentukan Sikap Mahasiswa Ilmu Komunikasi Fakultas Ilmu Sosial Dan Politik Universitas Sam Ratulangi." Acta Diurna Komunikasi 6, no. 1 (2017): 1-18.

Göner, Özlem, and Maria Six-Hohenbalken. "Gender and Memory in the Middle East: On Transgenerational Transmission and Agency." Dialectical Anthropology 43, no. 2 (June 1, 2019): 157-159.

Hopwood, Derek, Gordon Smith Charles, Arthur Eduard Goldschmidt, Raymond William Baker, Donald P. Little, and Peter M. Holt. "Arab Republic of Egypt, Arab Socialist Republic, Jumhūrīyat Mișr al- 'Arabīyah, Mișr.” Encyclopedia Britannica, $\begin{array}{lllll}\text { October 2019. January } & \text { Accessed }\end{array}$ https://www.britannica.com/place/Egypt.

Izzan, Ahmad. Metodologi Pembelajaran Bahasa Arab. Bandung: Humaniora, 2015.

Kushartati, Untung Yuwono, and Multamia RMT Lauder, eds. Pesona Bahasa: Langkah Awal Memahami Linguistik. Jakarta: PT Gramedia Pustaka Utama, 2005.

Long, Michael H, Gisela Granena, and Yucel Yilmaz. "Major Research Issues in Sla." Brill Research Perspectives in Multilingualism and Second Language Acquisition 1, no. 1 (2016): 1-86.

Misran. "Dialek "Ammiyyah Dalam Pengajaran Bahasa Arab Untuk Pariwisata Di Indonesia.” Adabiyyāt: Jurnal Bahasa dan Sastra 12, no. 2 (2013): 398-423.

Montgomery, James E. "Al-Jāḥiz on Misarticulation: Bayān 1.34.4-74.8." Journal of Arabic Literature 49, no. 1-2 (May 2018): 1-22.

Mufrodi. "Fonologi Dan Morfologi Bahasa Arab Amiyah Mesir." Arabiyat: Jurnal pendidikan Bahasa Arab dan Kebahasaaraban 2, no. 2 (December 2015): 192-215.

Mujib, Ahmad. "Hubungan Bahasa Dan Kebudayaan (Prespektif Sosiolinguistik)." Adabiyyāt: Jurnal Bahasa dan Sastra 8, no. 1 (2009): 141-154.

Muna, Naeila Rifatil. "Psikologi Pembelajaran Bahasa Arab." El-Ibtikar: Jurnal Pendidikan Bahasa Arab 1, no. 1 (2016): 102-126.

Noupal, Muhammad. "Bahasa Arab 'Amiyah Dan Fushah Suatu Narasi Deskriptif." Jurnal Al-Bayan 1, no. 2 (2010): 1-11.

Pancarani, Afridesy Puji, Zaqiatul Mardiah, and Miranda Ariadna Ayu. "Bahasa Amiyah Mesir (sejarah, Kaidah, dan Perbedaannya dengan Bahasa Arab Klasik" 3. jurnal Al Azhar Indonesia Seri Humaniora (March 2016): 205. 
Petré, Peter, and Van de Velde Freek. "The Real-Time Dynamics of the Individual and the Community in Grammaticalization." Linguistic Society of America Language 94, no. 4 (2018): 867-901.

S. Poedjosoedarmo. "Perubahan Bahasa." In Ceramah Ilmiah Linguistik Pada Pusat Kajian Melayu-Jawa. Fakultas Sastra Universitas Sebelas Maret Surakarta, 2008.

Sholihatin, Anis. "Pemilihan Kode Pada Masyarakat Keturunan Arab Di Nyoyontaan, Kota Pekalongan: Kajian Sosiolinguistik." Universitas Diponegoro Semarang, 2008.

Siddik, Mohammad. Pengembangan Model Pembelajaran Menulis Deskripsi. Malang: Tunggal Mandiri Publishing, 2018.

Supriyanto, Dedi. "Perbedaan Bahasa Arab Mesir Ragam Fusha Dan Amiyah," July 10, 2019. Accessed January 6, 2020. https://p4tkbahasa.kemdikbud.go.id/2019/07/10/perbedaan-bahasa-arab-mesirragam-fusha-dan-amiyah/.

Thompson, Levi. "Modern Arabic Poetry: Revolution and Conflict, Written by Waed Athamneh." Journal of Arabic Literature 48, no. 3 (2017): 340-344.

Tohe, Achmad. "Bahasa Arab Fusha Dan Amiyah Serta Problematikanya." Jurnal Bahasa dan Seni 33 (2005): 202.

Tovar, Sofía Torallas. 'Linguistic Identity in Graeco-Roman Egypt.' The Multilingual Experience in Egypt, from the Ptolemies to the Abbasids." Routledge (2016): 27 56.

Wahyudi, and Muhammad Ridha. "Urgensi Mempelajari Psikolinguistik Terhadap Pembelajaran Bahasa.” Jurnal Islamika 17, no. 1 (2017): 113-140.

Yendra. Mengenal Ilmu Bahasa (Linguistik). 1st ed. Yogyakarta: Deepublish, 2018.

Yoyo. "Pengaruh Bahasa Arab Terhadap Identitas Sosiokultural Dan Keagamaan Masyarakat Koptik Di Mesir.” Jurnal CMES 10, no. 1 (2017): 1-14.

Yoyo, Abdul Mukhlis, and Thonthowi. "Investigating the Use of Arabic Terms on Sociopolitical Context during the Arab Spring." In Prosiding Pertemuan Ilmiah Internasional Bahasa Arab, 1263-1273. Aceh, 2018.

Yoyo, Abdul Mukhlis, Thonthowi, and Ferawati. "High Variety vs Low Variety Culture in The Arabic Language: The Tensions between Fushâ and 'Âmiyya in The Contemporary Arab World." Arabi : Journal of Arabic Studies 5, no. 1 (2020): 2532. 